Article

\title{
Realizing a Circular Concrete Industry in Denmark through an Integrated Product, Service and System Perspective
}

\author{
Yana K. Ramsheva ${ }^{1, *(\mathbb{D})}$, Rikke M. Moalem ${ }^{2}$ and Leonidas Milios ${ }^{3} \mathbb{D}$ \\ 1 Department of Planning, Aalborg University, Rendsburggade, 149000 Aalborg, Denmark \\ 2 Department of Planning, Aalborg University, A.C. Meyers Vænge, 122450 København SV, Denmark; \\ rikkekr@plan.aau.dk \\ 3 The International Institute for Industrial Environmental Economics (IIIEE), Lund University, P.O. Box 196, \\ 22100 Lund, Sweden; leonidas.milios@iiiee.lu.se \\ * Correspondence: ramsheva@plan.aau.dk; Tel.: +45-52-816-079
}

Received: 19 October 2020; Accepted: 9 November 2020; Published: 12 November 2020

check for updates

\begin{abstract}
Concrete is the most commonly used material worldwide, often associated with an irreversible production process and waste generation at the end-of-life. As such, the concrete industry holds large untapped potentials for moving towards more circular economy (CE) practices. Product service system (PSS) offerings incentivize CE through extending product use, improving product performance and developing responsible end-of-life and take-back strategies. A broader definition of the concept of PSS is suggested, and a conceptual framework for realizing CE at the 'product', 'service' and 'system' dimensions is provided. The framework is applied to the case of concrete industry in Denmark. The aim was to cast new light on how the concrete industry can realize CE through a broader 'product', as well as 'service' and 'system' perspective. The selected case is analyzed through nine semi-structured interviews, additional secondary data, and follow-up dialogue with selected stakeholders. Results indicate a 'product' perspective may lead to savings on input material cost, improved efficiency of resource use, and reduced concrete waste quantities. A 'service' perspective can bring new market opportunities for concrete producers to adapt solutions to users' needs. A 'system' focus calls for new forms of organization and collaboration, as well as the expansion of networks within and across different stakeholder groups.
\end{abstract}

Keywords: product service system; circular economy; collaboration; concrete industry; case study

\section{Introduction}

Circular economy (CE) opens up new business opportunities for moving away from the currently established linear economy [1] and unsustainable consumption patterns of modern society [2,3]. Concrete is the most commonly used material worldwide, and as such the concrete industry plays a central role in today's society and the development of the built environment [4]. Being associated with large amounts of waste generation at the end-of-use of buildings, the concrete industry holds large untapped potentials for moving towards more CE practices [5]. Numerous cases exist related to initiatives for recycling concrete aggregates after demolition [6-9], reuse of concrete elements through deconstruction [10,11], and designing buildings with long-lasting concrete materials [12]. Despite such initiatives, the industry is in practice still largely driven by a mind-set of unlimited resource availability and increasing sales through traditional producer-customer transactions.

For the concrete industry to realize $\mathrm{CE}$, there is a need for attention beyond traditional product sales and ownership [13]. Product service system (PSS) offerings focus on extending product use and on improving product performance, as well as on responsible end-of-life and take-back strategies, 
as such contributing to CE [14]. Developing PSS offerings brings benefits to customers, businesses, and society as a whole [15].

As a respond to the somewhat narrow product focus of the concrete industry, this study suggests analysis of the sector with a wider PSS scope, expanding on the traditional definitions of PSS found in literature. In this study, PSS is perceived as consisting of the three dimensions of: 'product' (tangible), 'service' (intangible associated with the product) and 'system' (interrelated products and services in an embedded socio-technical context-both spatial and temporal).

At large, there is a lack of studies on the concrete industry that analyze the opportunities of CE holistically from a 'product', 'service' and 'system' perspective, as well as the underlying challenges for realizing those opportunities. Studies on the concrete industry generally consider concrete merely as a 'product' rather than a 'service' in a larger 'system' of building elements. A broader 'system' view is needed for moving not only the concrete industry, but the whole construction sector towards CE practices [16]. This is critical since identifying and analyzing the underlying CE opportunities and challenges from a 'product', 'service' and 'system' dimension may cast new light on how the concrete industry can successfully realize $\mathrm{CE}$.

Applying a broader 'service' and 'system' perspective on CE entails going beyond the cement and concrete production sites and engaging construction sector stakeholders. Establishing collaborative activities between stakeholders in CE networks for sharing knowledge and information is considered essential for reducing environmental impact of industries [17-19]. In a CE, stakeholders are not viewed in isolation but rather as part of a circular 'system' where they can generate joint interests and advantages through collaboration [20]. This is supported by an assessment of CE in the construction sector by the Nordic Council of Ministers, which repeatedly underlines the importance of cross-sector collaboration for realizing CE potentials [21]. In line, Leising et al. [22] suggest involving all stakeholders in the value chain of the construction sector (designers, material/product suppliers, building companies, waste companies, etc.) to further CE efforts. Summing up, academic and business professionals highlight the importance of collaboration across the value chain to address challenges and harvest potentials of $\mathrm{CE}$ in the concrete industry. As a supplement to the current product-oriented literature, there is a need for an industry-specific analysis on the role of stakeholder collaboration also at a 'service' and 'system', level.

Through industry analysis with a three-dimensional conceptual CE framework, the study explores the following research question:

\section{How can a 'product', 'service', and 'system' perspective support realizing CE for the concrete industry?}

Qualitative research is conducted in order to address the raised research question. Analysis of relevant CE and PSS literature is presented in Section 2, which is then used in Section 3 to develop an initial conceptual framework for analyzing the case study-the concrete industry in Denmark-in a 'product', 'service' and 'system' dimension. Section 3 continues with the description of the industry case and the applied qualitative methods for data collection, i.e., interviews, written documents, follow-up dialogues. Section 4 presents the analysis of the case, facilitated by the application of the initial conceptual framework on the empirical material gathered from the concrete industry in Denmark. CE opportunities, existing challenges, and the role of inter-organizational collaboration in each of the three dimensions of 'product', 'service' and 'system' are explored. Section 5 includes a discussion on the managerial implications for the concrete industry in the transition towards more circular operations. Conclusions are drawn in Section 6.

\section{Background}

\subsection{The Notions of CE and the Existing Link to PSS}

In recent years, attention towards $\mathrm{CE}$ has been growing among industries, authorities and the academic community [23]. CE is seen as an alternative to the currently established linear economy [24,25], driven by the notions of narrowing, closing, and slowing resource loops [23,24]. Narrowing resource 
loops means focusing on efficient use of resources, reducing resource input for a unit of output [23]. Closing resource loops aims at recovering, recycling, or reuse of residual value from resources after the end of their use phase, while slowing refers to design for disassembly, repair and maintenance as a way to delay products' end-of-life [25]. Konietzko et al. [23] added a fourth notion of regenerate, linking to reshaping the production process by eliminating toxic materials and using renewable energy. Diverse technologies and big data can also be considered a supporting element of $\mathrm{CE}$ in some instances (e.g., improving resource efficiency through prolonging product lifetime, enable recovery of valuable resources, etc. [24]), defined by Konietzko et al. [25] as the notion of inform. Bocken et al. [24], Konietzko et al. [25], and Murray et al. [26] claimed the five notions of CE are interrelated and a 'system' focus can help understand the true effect of their application. Therefore, in this study the above-described five notions of $\mathrm{CE}$ are used as guiding principles for analyzing how $\mathrm{CE}$ can be realized in 'product', 'service' and 'system.

In addition, a sixth notion of sustain is suggested by the authors, as a way to address the unbalanced focus on the environmental, economic and societal impacts in CE literature [26]. Focus on the triple bottom line emphasizes the importance of $\mathrm{CE}$ to generate economic and environmental value, as well as contributes to solving societal needs, which should be just of central priority. Furthermore, sustain is defined in this study as an overarching notion for industrial systems to follow the principles of natural ecosystems-being complex, but highly adaptive and self-sustaining [27]. In nature, waste is considered non-existent and resources are managed in the most effective way. In the currently established linear economy, more weight is placed on creating economic gains of individual firms compared to facing environmental or social challenges $[20,28]$. The authors suggest that, if the concrete industry, as well as other industries, broaden their perspective and perceive the 'system' around them (including the stakeholders within that system) as an interconnected body of networks that interact and have the ability to work beyond solely maximizing own profits-but looking for extended profits to the society on which they depend on -, then innovative sustainable solutions can be created.

Existing academic literature links the concepts of CE and PSS in diverse ways [29]. Corvellec and Stål [30] suggested the importance of PSS as a way to prioritize waste prevention strategies prior to reuse and recycling. Similarly, Chen and Huang [31] analyzed the need of integrating life-cycle assessment with PSS in CE setting for reducing, reusing, and recycling resources. Based on a literature review, Michelini et al. [32] concluded that PSS can be considered an enabler of CE, as it encourages resource efficiency and product life-extension. Halstenberg and Stark [33] developed and tested a software model facilitating CE through PSS by designing products for reuse. Kühl et al. [34] looked at service offerings in a CE and highlighted the importance and current lack of focus on retrieving and recovery of products after their use phase. Reim et al. [35] classified and compared three groups of PSS, i.e., oriented towards the physical product, product use though a lease/rental contract, a solution for a users' need, and emphasized the central role of creating networks and partnerships in the context of PSS. Despite present studies, uncovering relevant points linked to CE and PSS, questions, such as 'how can CE be realized in 'product', 'service' and 'system' dimension and what opportunities and challenges that may bring', to our knowledge, still demand further investigation.

\subsection{From PSS to 'Product', 'Service' and 'System'}

PSS is defined as a tool that integrates products and services, which have the aim to satisfy the needs of the customers and maintain sustainable resource use [36]. The topic of product-service system (PSS) as an integration of products and services has been under analysis since the 1990s. There is still not an unified definition of PSS; nonetheless, scholars generally agree that PSS incentivizes a transition from a product focus towards a service focus "designed to be economically, socially and environmentally sustainable, with the final aim of fulfilling customer's needs" [37]. Including a service to a given product is also considered a mean for extending the products' life-time and, as such, contributing to a CE [38].

Goedkoop et al. [39] suggest PSS be viewed as a combination of tangible products and services that bring commercial value. In a CE context, such a narrow view at the system, only as a collection 
of elements, does not include the importance of interaction between stakeholders as a mean for developing circular solutions to societal needs instead of only meeting current demand desires [40].

Tukker [36] presents a widely-used classification of PSS based on three categories, i.e., product, use, result-oriented PSS, linking to diverse ways to meet customer needs and enable resource efficiency of the offering. The product-oriented PSS places the product in the center and the service (e.g., takeback after end-of-life) as an add-on to the product; use-oriented PSS offers a service instead of the actual product (e.g., leasing or renting the product); result-oriented PSS suggests providing the outcome instead of a product or a service (e.g., indoor lightening, instead of selling/leasing lightbulbs) [35]. Still, this classification has also met criticism as it directs the attention towards the question of product ownership and is thus considered too simplified to encompass the complexity of PSS [41]. Through a framework for sustainable value propositions in PSS, Kristensen and Remmen [40] make an interesting point by proposing to look at PSS not simply as an "add-on" service to a product but instead view the 'product', 'service' and 'system' as different levels, where stakeholder interaction play a central role for creating value.

In this study, an even broader perspective to the concept of PSS is suggested, as a three-dimensional concept, including the dimensions of 'product', 'service' and 'system'. 'Product' represents tangible products, e.g., raw materials and final goods and value chain activities linked to the product. 'Service' includes the products or collection of products and associated processes that be of service to the end user. 'System' is defined as space within certain physical limits, for example, an eco-industrial park or an urban area bounded by a geographically defined space [42], that includes a cognitive network of stakeholders operating within that space under a common set of rules. All collaborative activities between stakeholders provide products and services that aim at bringing a solution to sustainability (environmental, economic, societal) needs or challenges.

It is important to underline that the three dimensions should not be looked in isolation from one another. Moving focus from one dimension to the next, i.e., 'product' to 'service' or from 'service' to 'system', requires building on the ideas and activities related to the preceding dimension. A shift of focus from solely the 'product' towards 'service' and improvements on a 'system' can raise economic, environmental and societal gains [23,40]. The considerations made in Section 2.2 are used as foundations for developing a conceptual framework for realizing CE in 'product', 'service' and 'system', presented in the following section.

\section{Methodology}

\subsection{Research Design}

Figure 1 presents a step-by-step illustration of the research design, followed in this study to address the previously raised research question. Firstly, the existing literature on CE and PSS was analyzed and the broader view of the three dimensions of 'product, 'service' and 'system' was defined (see Section 2). Secondly, a conceptual framework for realizing CE in 'product', 'service', and 'system' was developed (Section 3.2), illustrating how the notions of CE link to each of the three dimensions of 'product, 'service' and 'system'. Thirdly, in order to empirically analyze how the concrete industry could realize $\mathrm{CE}$ in each of the three dimensions, a case study research was conducted. The case of the concrete industry in Denmark (Section 3.3) and the methods for data collection and analysis (Section 3.4) are described in detail. Lastly, the initially suggested conceptual framework was applied to the case study (Section 4). Managerial implications deriving from the analysis of the case study for the concrete industry in Denmark are discussed in Section 5. 


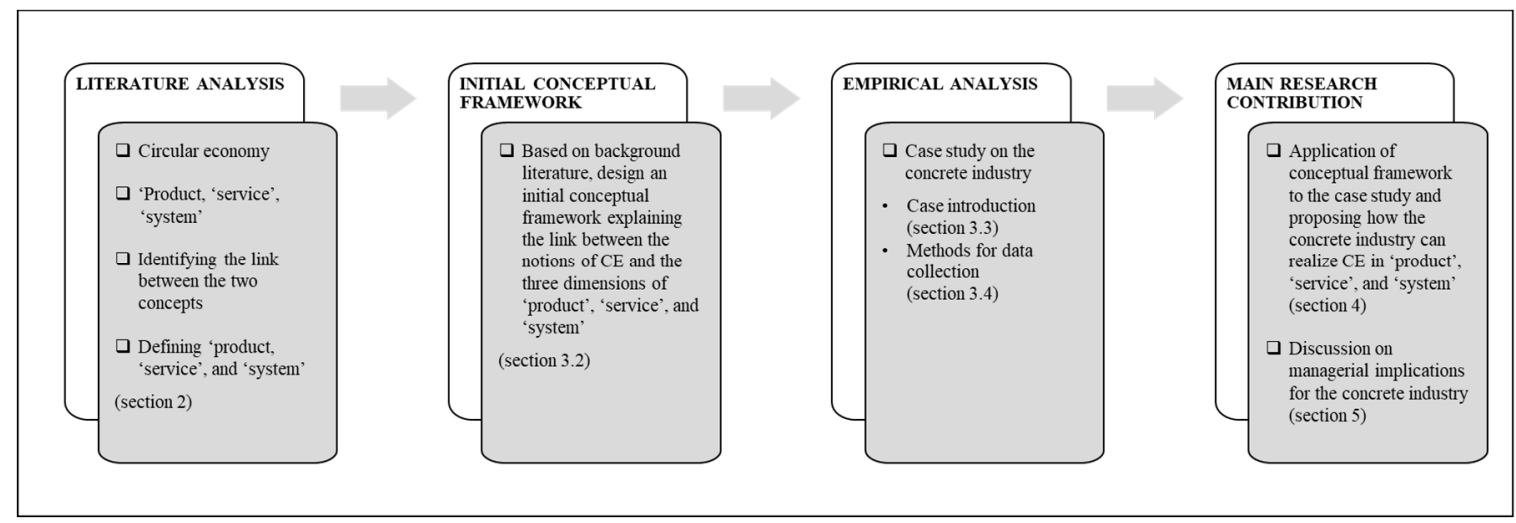

Figure 1. A step-by-step overview of the research design of this study.

\subsection{Initial Conceptual Framework for Realising CE in 'Product', 'Service and 'System'}

Based on the analysis of the existing literature on CE and PSS, as well as the proposed three-dimensional focus on 'product', 'service' and 'system' by the authors, an initial conceptual framework for realizing CE in 'product', 'service' and 'system' is suggested in Figure 2.

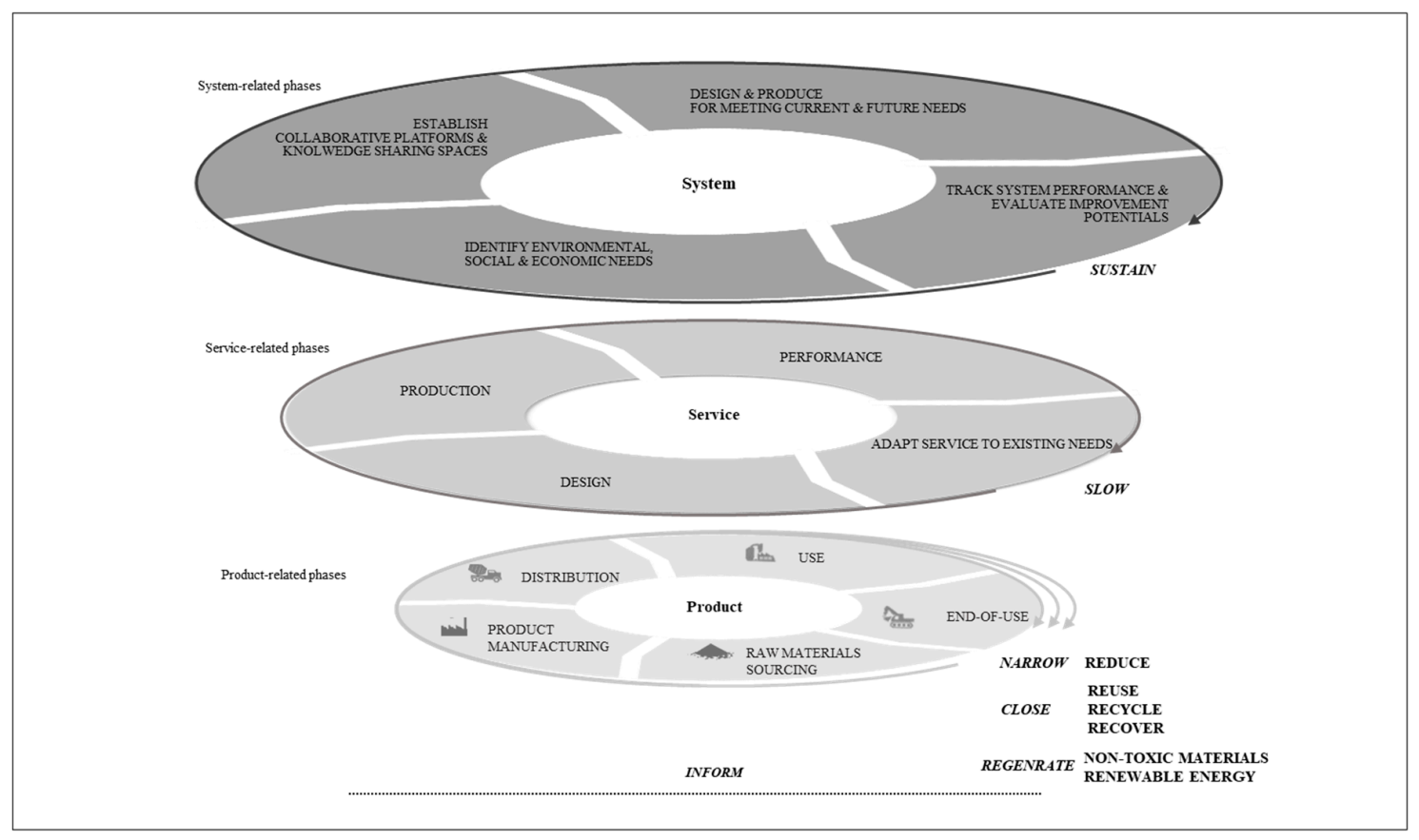

Figure 2. A visualization of a framework for realising circular economy (CE) in 'product', 'service' and 'system', based on the notions of CE by Bocken et al. [24] and Konietzko et al. [25] interpretation.

The first layer of the framework represents the 'product' dimension and the product-related phases, i.e., raw material extraction, product manufacturing, distribution, use, end-of-use. The notions of narrow (reduce), close (reuse, recycle, recover), and regenerate (use of non-toxic materials, renewable energy, etc.) are associated to the 'product' dimension, as they have an effect on the environmental impact on the product and an on extending the product or material value [24]. According to the waste hierarchy, activities that carry the best possible environmental outcome should be prioritized, starting from waste prevention, preparation for reuse, recycling, recovering, and, finally, when no other option is possible, disposal [43]. This conceptual framework follows the prioritization laid in the waste hierarchy. Some of the activities for narrowing and closing resource loops enable the recovery and reuse of products and materials, as well as reduction of consumption of fewer resources. Regenerate supports 
the design of sustainable products and the sustainable use of resources (e.g., renewable energy sources during all processes, avoid toxic materials, recirculate water and nutrients, etc.).

The 'service' dimension incorporates the product or collection of products and suggests activities that can service the end user. Design, production, performance, and adapting service to customer needs are all service-related activities directed at creating a 'service' that can meet existing needs. In order for $\mathrm{CE}$ to be realized in such setting, attention on designing flexible solutions for possible extension of product life-time through disassembly, maintenance, repair, monitoring performance is needed [25]. Such solutions can slow the resource flow and make it possible to keep resources in the economy for longer.

The 'system' dimension incorporates products and services, embedded by a socio-technical context-both spatial and temporal. The 'system' exhibits the following four phases, i.e., identify environmental, economic, and social needs; create spaces for knowledge/expertise sharing and collaborative learning platforms; design for meeting current and future needs; track system performance and evaluate improvement potentials. By definition, more than one actor is involved in a 'system', and as such, interaction between stakeholders is recognized as essential element for reaching a certain goal in a 'system'. Involving a number of stakeholders, each with their expertise and challenges can also bring uncertainties throughout the process. As such, in order CE to be realized, the 'system' needs to sustain itself, by being able to adapt to changes both internally and externally and keep a balance between creating environmental, economic, and social gains. Similar to Konietzko et al. [25] view on the importance of digital technologies, big data, and the internet of things (IoT) in a CE, the notion of inform is highlighted as a supporting strategy in all three dimensions.

The framework should be viewed from bottom and upwards, i.e., from 'product' towards the 'system', and the dimensions should not be seen in isolation from one another. 'Product' is incorporated in the 'service', while the 'system' embraces both 'product', as well as 'service'. In a CE, a 'product' focus is mainly aimed at improving performance on a product level, while a service focus intends to bring value to the customer during the use phase of the 'product' (see Reim et al. [32]). A 'system' focus goes beyond capturing CE potentials of a single company, and encompasses all stakeholders in a 'system' [25]. Implementing CE in 'system' involves collaboration between stakeholders (see Bocken et al. [19]), i.e., raw material suppliers, producers, service providers, and society. Such collaboration is recognized as being successful and vital in bringing solutions to societal needs and not only addressing current demand desires [40]. Since the proposed framework is built only on literature, it cannot not be expected to apply universally to all industries without further development. Through the case on the concrete industry in Denmark, additional details to the framework are uncovered and the role of collaboration in each dimension of 'product', 'service', and 'system' is further analyzed; see Section 4.

\subsection{Case Introduction}

A single case study design is applied as a tool for analysis, since a case study is considered useful for describing and understanding a complex phenomenon [44]. Case studies are, in general, the preferred method when posing "how" or "why" questions, when the investor has little control over events and focus is on contemporary phenomena within a real-life context [45].

In this study, the case on the concrete industry in Denmark is analyzed. Just as in other countries, concrete is the most used building material in Denmark, and its demand is only expected to increase due to population growth and urbanization. A central focus of the industry has been optimizing energy and water use [46], reducing $\mathrm{CO}_{2}$ emissions, a large amount of which are mainly associated with the production of cement [47], and retrieving concrete waste for crushing it for road base [48] — the most common scenario for handing concrete waste in Denmark. Yet, growing attention on CE in all industrial sectors create the need for improving the concrete industry further and identify new ways to create value within a CE. Application of the notions of $C E$ in the concrete industry are today mainly linked to minimizing waste during construction and concrete recycling [17]. Both in Denmark and worldwide, recycling is a well-established process for handling concrete waste after demolition [4,49]. Concrete 
waste in Denmark accounts for $25 \%$ of all construction waste, or in other words, more than 1 million tonnes per year [50]. The reason for the large amounts of concrete waste generation is that concrete is rarely reused during renovation process or in new constructions. Instead, in order to avoid landfilling, about $90 \%$ of the concrete waste in Denmark is crushed and used as road-base, fillings, or other lower value applications [50], leaving numerous untapped CE potentials for the concrete industry. This study focuses on uncovering such CE potentials and proposes a conceptual framework for realizing CE in the concrete industry. In order to do so, nine actors from the concrete industry are identified based on organizational size and main activities, as well as their potential engagement with CE activities.

One of the relevant stakeholders in the concrete industry in Denmark is the architecture company responsible for the "Circle House" project, Denmark's first circular housing "constructed according to the principles of circularity". The aim of the project is using $90 \%$ reusable materials, among which also concrete [51]. This includes a building system based on concrete elements and mechanical joints. Involving relevant actors in a collaboration to create joint solutions is considered key for achieving the "Circle House" project ambitions. Moreover, the first part of the demonstration project-The Circular House Demonstrator, a 1:1 mock up and exhibition space-is already realized. Analyzing the learnings from that demonstration project is an important source of data for this study, especially with regard to the technical and organizational opportunities and challenges to realize $\mathrm{CE}$ in the context of concrete.

\subsection{Data Collection Methods and Data Analysis}

Data on the case of the concrete industry in Denmark is collected through a mix of qualitative methods. Nine semi-structured interviews with stakeholders from the concrete industry involved in diverse CE activities are planned, conducted and analyzed. Internal data and reports from the involved organizations in the interviews is used a supplement material to the collected interview data. In order to affirm the gained understanding on the case and ensure validity of the collected data [52], follow-up dialogue with selected stakeholders from the concrete industry is conducted. Applying those three methods provides the possibility to create an elaborate understanding of the underlying $\mathrm{CE}$ opportunities and existing challenges that hinder realizing $\mathrm{CE}$ in the concrete industry, as well as the role of collaboration between stakeholders.

Due to the exploratory nature of this study, conducting interviews is considered a useful method for gaining an understanding of others perception and opinions [52]. A list of interviewees, their function, their organization focus and main CE activities are summarized in Table 1. The nine interviewees are selected based on their crucial involvement in the value chain of concrete, covering all aspects of design, raw material production and conversion into final products, construction, use and end-of-life [53]. The interviews are purposely fitted for understanding the industry's reality and get unbiased data on already employed CE activities by the industry in 'product', 'service' and 'system' dimensions. Furthermore, the role of stakeholder collaboration in each of the dimensions is discussed based on the interviewees' experiences in the process. Seven of the interviews are video recorded, two are audio recorded, detailed notes are taken during the interviews and main points, and conclusions are written. Reflections from the "Circle House" collaboration process are analyzed through three of the conducted interviews for this study, i.e., interviewee nr. 5 and nr. 6, who both took part in the "Circle House project, as well as interviewee nr. 8 , who is a representative from the architecture company leading the project.

The interview guide is included in Table 2.

Triangulation of methods and data sources is applied in order to create a more elaborate understanding of the analyzed subject and ensure the reliability of data [44]. This study applies triangulation in two ways. First, analyzing interview data in combination with content analysis of internal data and reports provided by the respective organizations involved in the interviews. Second, engaging in a follow-up dialogue with relevant stakeholders from the concrete industry. More specifically, those stakeholders are two employees from the interviewed organizations working with development of sustainable concrete materials, as well as two academic experts from a leading research institute for the built environment in Denmark. 
Table 1. Overview of conducted interviews.

\begin{tabular}{|c|c|c|c|}
\hline No. & Employee Function & Activity of the Organization & Main CE Activities \\
\hline 1 & Senior concrete technologist & cement production and distribution & $\begin{array}{l}\text { Establishing industrial symbiosis (contributed to reduction of virgin resource use, energy use, } \\
\text { greenhouse gas emissions) } \\
-\quad \text { waste and by-products from other industries as alternative materials and fuels } \\
\text { - } \quad \text { excess energy from production for district heating purposes } \\
\text { - cold water from quarry for district cooling purposes }\end{array}$ \\
\hline 2 & Production director & $\begin{array}{l}\text { ready-mix concrete production and distribution to building sites, } \\
\text { concrete casting }\end{array}$ & $\begin{array}{l}\text { Recover and recycle concrete } \\
\text { Emission-free construction sites } \\
\text { Reuse of surface water }\end{array}$ \\
\hline 3 & Business developer & household and industrial waste handling & $\begin{array}{l}\text { Recycle, repair and upcycle materials and other recovered products, including concrete after } \\
\text { demolition process }\end{array}$ \\
\hline 4 & Municipal team leader & municipal household and industrial waste handling & $\begin{array}{l}\text { Recover, recycle and utilise diverse waste materials, including concrete from concrete } \\
\text { producers or demolition processes } \\
\text { Sorting and crushing concrete waste to be used as paving stone, road-base or asphalt as a } \\
\text { substitute of virgin aggregates (ex. gravel) }\end{array}$ \\
\hline 5 & Project leader & partnership organization for sustainable renovations & $\begin{array}{l}\text { Involve all value chain stakeholders from the construction industry for improving the } \\
\text { renovation process of buildings in terms of: } \\
\text { - } \quad \text { material optimization } \\
\text { - } \quad \text { design for disassembly }\end{array}$ \\
\hline 6 & Technical manager & concrete elements production, design, delivery, assembly, service & $\begin{array}{l}\text { Design for disassembly } \\
\text { Reuse of concrete elements }\end{array}$ \\
\hline 7 & Director & concrete connections and composite beams production & $\begin{array}{l}\text { Design for disassembly/design flexible infrastructures } \\
\text { Reduction of quantity input material per module output }\end{array}$ \\
\hline 8 & Architect & innovation unit focused on circular design, digital design & $\begin{array}{l}\text { "Circle House" project responsible } \\
\text { Design of "circular buildings" by involving all value chain stakeholders } \\
\text { (incl. interviewed organizations no. } 2 \& 3 \text { ) } \\
\text { Design for disassembly/flexibility/circularity } \\
\text { Optimization of construction time } \\
\text { Optimization of infrastructure maintenance through the support of digital technologies }\end{array}$ \\
\hline 9 & Director & $\begin{array}{l}\text { Danish concrete industry association focused on promoting the } \\
\text { interests of the concrete industry }\end{array}$ & $\begin{array}{l}\text { Dissemination of knowledge of concrete (properties, production process, use) } \\
\text { Ensure member interests in front of authorities, contractors, other institutions, general public } \\
\text { Promote cooperation between members of the association }\end{array}$ \\
\hline
\end{tabular}


Table 2. Interview guide.

\begin{tabular}{|c|c|c|}
\hline & Topic & Questions \\
\hline 1 & $\mathrm{CE}$ activities already initiated & $\begin{array}{l}\text { - How engaged is the company in working with CE? } \\
\text { - } \quad \text { Are CE initiatives/strategies already initiated? In what way? }\end{array}$ \\
\hline 2 & CE opportunities & $\begin{array}{l}\text { - Are you currently involved in any (research) projects or in } \\
\text { collaboration (within the building industry) on circular } \\
\text { economy solutions? } \\
\text { - How (would you consider) the future building sector would } \\
\text { work with CE? }\end{array}$ \\
\hline 3 & Existing barriers and challenges & $\begin{array}{l}\text { - How would you define you biggest challenge in working } \\
\text { with CE? } \\
\text { What barriers do you consider hinder the realization of CE } \\
\text { opportunities (e.g., political, market, economic, societal, } \\
\text { technological, etc.)? }\end{array}$ \\
\hline 4 & The role of collaboration & $\begin{array}{l}\text { How large is the importance of collaboration with partners } \\
\text { along the value chain today? } \\
\text { What role do you consider collaboration may have in a } \\
\text { CE setting? }\end{array}$ \\
\hline
\end{tabular}

\section{Applying the Conceptual Framework on the Case of the Concrete Industry in Denmark}

Based on the conducted interviews and additional data analysis, the conceptual framework is applied to the case of the concrete industry in Denmark; see Figure 3. CE opportunities for the industry, as well as existing challenges for realizing those, are identified for each of the three dimensions of 'product', 'service', and 'system'. In addition, the role of stakeholder collaboration in each dimension is highlighted. Findings are summarized in Table 3.

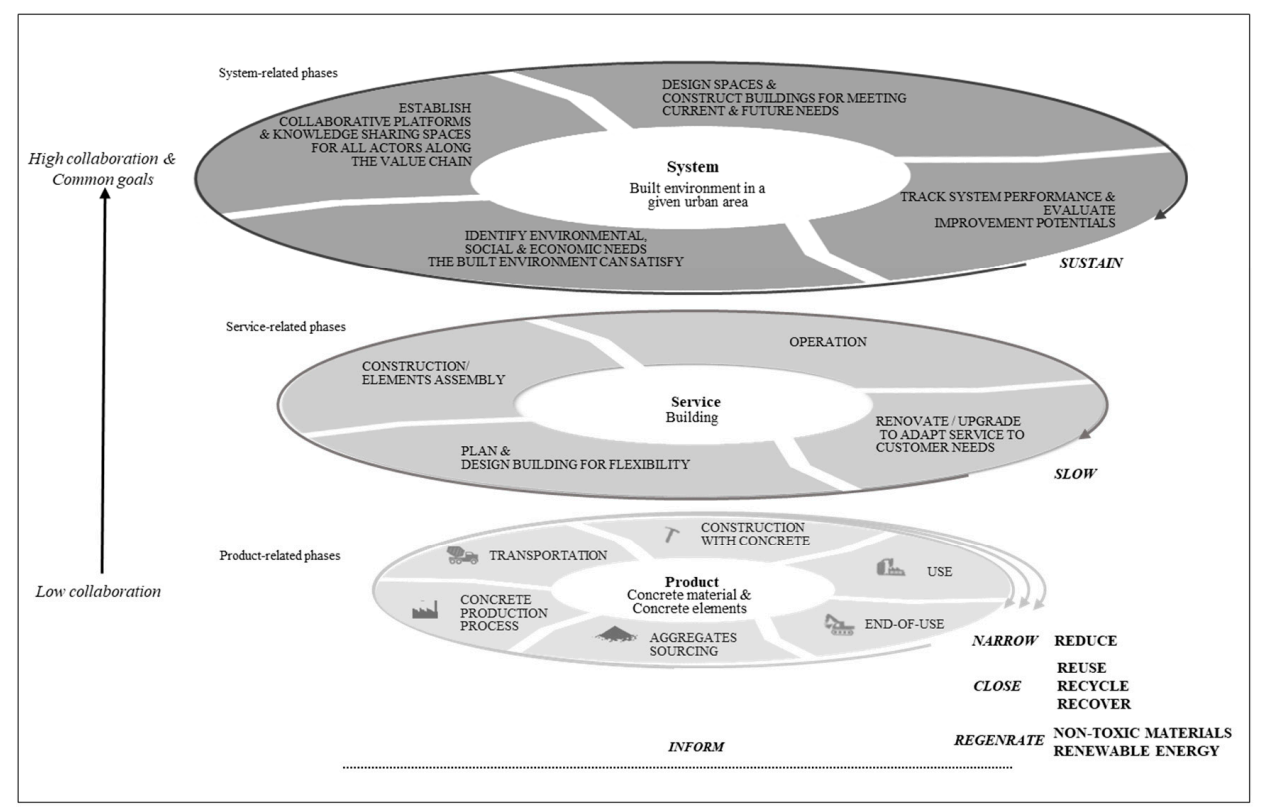

Figure 3. Framework for realizing CE in product, service, systems on the case of the concrete industry, based on the notions of CE by Bocken et al. [24] and Konietzko et al. [25]. The upwards pointing arrow suggests collaboration between stakeholders increases and its role is more crucial when focus is moved from the product towards the service and the system dimension. 
Table 3. CE opportunities, existing challenges for realizing those, as well as the role of stakeholder collaboration. A summary of the results obtained through data collection for this study.

\begin{tabular}{|c|c|c|c|c|c|}
\hline & \multicolumn{3}{|c|}{$\begin{array}{c}\text { PRODUCT } \\
\text { (Concrete Material and Concrete Elements) }\end{array}$} & \multirow{2}{*}{$\begin{array}{c}\begin{array}{c}\text { SERVICE } \\
\text { (Building) }\end{array} \\
\text { SLOW } \\
\text { (Design for Disassembly and Adaptability, } \\
\text { Monitoring and Renovation) }\end{array}$} & \multirow{2}{*}{$\begin{array}{c}\text { SYSTEM } \\
\text { (Built Environment in a Given } \\
\text { Urban Area) } \\
\text { SUSTAIN } \\
\begin{array}{c}\text { (Establish Collaborative Networks } \\
\text { for Sustainable Solutions) }\end{array}\end{array}$} \\
\hline & $\begin{array}{l}\text { NARROW } \\
\text { (Reduce) }\end{array}$ & $\begin{array}{c}\text { CLOSE } \\
\text { (Reuse, Recycle, Recover) }\end{array}$ & $\begin{array}{c}\text { REGENERATE } \\
\text { (Use of Non-Toxic Materials, } \\
\text { Renewable Energy) }\end{array}$ & & \\
\hline \multirow[b]{2}{*}{ CE opportunities } & \multicolumn{3}{|c|}{$\begin{array}{c}\text { Reduced environmental impact } \\
\text { (avoided emissions) and social impact assoc. with virgin aggregates sourcing or landfill } \\
\text { Reduced resource use } \\
\text { (virgin aggregates, water, energy) }\end{array}$} & \multirow{2}{*}{$\begin{array}{c}\text { New market opportunities } \\
\text { Improved indoor space use } \\
\text { Higher revenue margin } \\
\text { - Lower production costs of } \\
\text { mass-produced/low-variability of standardize } \\
\text { components (for pre-casted elements) } \\
\text { - Improved resource efficiency (material, energy, } \\
\text { water) and life-time of building materials } \\
\text { (incl. concrete) through service and renovation }\end{array}$} & \multirow{2}{*}{$\begin{array}{l}\text { Collaborative learning platform for } \\
\text { development of sustainable solutions and } \\
\text { competitive strategy } \\
\text { Effective utilization of resources } \\
\text { Addressed societal needs leading to } \\
\text { improved health and well-being }\end{array}$} \\
\hline & Savings on input material costs & $\begin{array}{l}\text { Additional value capture (reused concrete } \\
\text { or recovered and recycled concrete } \\
\text { aggregates) } \\
\text { Improved efficiency of resource use and } \\
\text { reduced waste quantities } \\
\text { Building a CE narrative for concrete }\end{array}$ & & & \\
\hline \multirow[t]{2}{*}{ Existing challenges } & $\begin{array}{l}\text { Environmental and social costs of } \\
\text { concrete currently not reflected in } \\
\text { the market price } \\
\text { Construction companies } \\
\text { unwilling to pay an extra cost for } \\
\text { "greener" concrete (with reduced } \\
\text { impact properties) }\end{array}$ & $\begin{array}{l}\text { Low cost of virgin aggregates and high } \\
\text { local availability in Denmark } \\
\text { A well-established process for recovering } \\
\text { concrete for the purpose of road fill } \\
\text { and paving } \\
\text { Current low landfill rate for concrete waste } \\
\text { in Denmark }\end{array}$ & $\begin{array}{l}\text { "Low-hanging fruit" } \\
\text { already achieved } \\
\text { High investment costs for research } \\
\text { and realization of new projects } \\
\text { (e.g., renewable energy plant, } \\
\text { recirculation and reuse water from } \\
\text { concrete production process, etc.) }\end{array}$ & $\begin{array}{l}\text { At present public tenders for construction } \\
\text { projects generally do not include requirements } \\
\text { for design for disassembly }\end{array}$ & $\begin{array}{l}\text { Platforms for collaboration and development } \\
\text { of sustainable solutions and competitive } \\
\text { strategy not considered "business as usual" } \\
\text { Existing legislation does not include specific } \\
\text { regulations and expectations for } \\
\text { implementing CE in the construction sector } \\
\text { Local government planning doesn't fully } \\
\text { support a 'system' focus when initiating area } \\
\text { plan for construction }\end{array}$ \\
\hline & \multicolumn{5}{|c|}{$\begin{array}{l}\text { Technology for monitoring performance of concrete, as well as of buildings not fully developed } \\
\text { Control over data storage and data ownership rights } \\
\text { for monitoring materials and product performance not in place }\end{array}$} \\
\hline $\begin{array}{l}\text { Cross-organizational } \\
\text { stakeholder } \\
\text { collaboration }\end{array}$ & \multicolumn{3}{|c|}{ Establishing dialogue and written agreements periphery to core activities } & $\begin{array}{l}\text { Collaboration for evaluating whether } \\
\text { a new/existing building provides the needed } \\
\text { 'service' to its users and find ways to adapt space } \\
\text { to users' needs }\end{array}$ & $\begin{array}{l}\text { Dynamic collaborative (physical and virtual) } \\
\text { environment for establishing common goals } \\
\text { and shared values }\end{array}$ \\
\hline
\end{tabular}


In the context of the concrete industry, 'product' is defined as a ready-mix concrete or pre-casted concrete elements. 'Service' encompasses all activities related to the construction process and facility management of a building. 'System' goes beyond the building and covers the whole built environment in a given urban area, including private and public stakeholders. Cities today develop at a faster rate than ever before [54]. Thus, defining a 'system' simply as a building that provides accommodation would be too narrow. Instead, a broader view of a 'system' as an urban built environment can enable exploring the possibilities for realizing $\mathrm{CE}$ that match both existing societal needs just as well as incorporating visions for the future development of an area.

\subsection{Realizing CE in 'Product' Dimension}

Following the notions of $\mathrm{CE}$ in 'product' dimension, narrow, close and regenerate mainly link to reduced environmental and social impact and reduced use of resources, e.g., virgin aggregates, water, energy, etc. The notion of narrow can furthermore contribute to savings on input material costs. The notion of close can enable additional value capture if concrete is reused, or if recovered and recycled concrete aggregates are utilized. Recover, recycling, and reuse of concrete lead to improved efficiency of resource use and reduced concrete waste quantities, which the concrete industry can use as part of the "narrative" of the CE potential for concrete.

A number of challenges for realizing the CE opportunities are identified through the collected data. At present, concrete producers consider the industry extremely price-dependent. Environmental and social costs of concrete are not reflected in the market price, and, at the same time, construction companies are unwilling to pay extra for concrete with reduced-impact properties. That makes working with $\mathrm{CE}$ a challenging task, mainly due to economic reasons. Interviewee 2 adds:

"for our normal day-to-day business, it is all customer-driven and if the customer asks for it, we can deliver ... it might come at a price",

yet, customers are often

"... not able to pay for "greener" product ... at the moment there is not anything in the tenders (requirements) ... describing greener concrete or circular economy"

Another challenge for incentivizing the notion of close and narrow is the currently low cost of virgin aggregates and their high availability in Denmark. In addition, there is a well-established practice for recovering concrete as road fill and paving in Denmark. That makes the current landfill rate of waste concrete quite low, which in turn, does not encourage the industry to look for more beneficial applications of 'end-of-use concrete'.

With regard to regenerate, "low-hanging fruits" are already reached through general regulations on emission-reduction, as well as energy-saving activities. Still, research and realization of new projects (e.g., renewable energy plant, recirculation, and reuse water from concrete production process, etc.) are generally associated with high investment costs for concrete companies. Lifting the CE challenges for creating concrete with reduced material input, that either includes recovered and recycled raw material or is designed for reuse, and produced with renewable energy, could enable CE potentials not only in 'product', but also in 'service' and 'system' dimension.

According to analyzed data, stakeholder collaboration is seen by organizations as beneficial, yet not compulsory for realizing $\mathrm{CE}$ in 'product' dimension. Collaboration in that dimension is mainly associated with establishing dialogue between partners and creating written agreements, which are considered periphery to core activities of concrete producers.

\subsection{Realizing CE in 'Service' Dimension}

In a 'service' dimension, moving away from the conventional construction methods that most often consider demolition as an end-of-use scenario, towards the design of concrete buildings for flexibility and disassembly enables CE in two ways. Firstly, it slows and delays end-of-use of a building when 
supported by continuous monitoring of performance for possible renovation and improvements. That can bring new market opportunities in terms of new 'service' offerings for the building users. Flexible building design can act as a solution against demolition. Adapting indoor space based on existing and future needs slows the resource loops and creates opportunities for waste prevention. Secondly, higher revenue margins can be generated due to lower variability of mass-produced standardized concrete components. As interviewee 8 mentions:

"it has to be a good business model ... the structure of the building is the last thing that we are going to reuse ... . with more flexible office for example it will be easier to adapt to fit a new customer"

Furthermore, the notion of slowing enables CE not only in 'service' but also in the 'product' dimension, as when adaptability of functional spaces is not an option, disassembly and reuse of materials is made possible, supporting improved efficiency of resource use.

Two main challenges are identified for realizing CE in 'service'. The construction sector is still led by the linear "cradle-to-grave" model, which is also reflected in present planning, construction and use of buildings. In addition, at present, public tenders for new construction projects do not include specific requirements for $\mathrm{CE}$ at the end-of-use of buildings. Interviewee 3 underlines how municipalities in Denmark often consider buildings at end-of-life:

"Unfortunately, screening reports (prior to demolition) are requested to include information about reuse or recycling, but I am afraid in most cases they (demolition companies) don't really distinguish between reuse and recycling. A priority should be on the reuse if possible, if not possible-it should be on recycling, and if that is not possible, other solutions should be considered."

Inter-organizational collaboration plays a more central role in this dimension. It may occur at different service-related phases and involve suppliers, service and maintenance providers, and renovation responsible in order to ensure the 'service' meets users' needs.

\subsection{Realizing CE in 'System' Dimension}

In a 'system', organizations responsible for the development and maintenance of the built environment in a given urban area are considered interconnected, " . . if we want to build "circular", the whole chain needs to follow, everybody needs to be present". That gives the opportunity to establish a collaborative learning platform for developing solutions that take into account social, environmental and economic perspectives and, at the same time, provide competitive strategy for all stakeholders. In such a setting, resources can effectively be utilized, societal needs can be addressed, and health and well-being of citizens can be improved.

A number of challenges are present for enabling those CE opportunities in 'systems'. Establishing platforms for collaboration and development of sustainable solutions and competitive strategy are not considered "business as usual" in the concrete industry. Furthermore, local government planning does not fully support a 'system' focus when initiating an area plan for construction, nor does existing legislation include specific regulations and expectations for implementing $\mathrm{CE}$ in the building sector:

"one of the big challenges for us as producers ... we only enter the projects at a very late stage ... and connections are already decided and fixed, and to push a little and influence the choice of connections and geometries was a very good things for us ... and to have our concerns and opinions heard."

The "Circle House" project provides relevant insights on how some of the identified CE challenges in a 'system' dimension could be overcome. Being the first experiment on Danish ground, in "Circle House" establishes a collaborative learning platform for stakeholders with a common goal of integrating $\mathrm{CE}$ solutions to create sustainable housing in a given urban area. According to the stakeholder responsible for driving the "Circle House" project, a core element in realizing CE in a 'system' dimension requires getting familiar with the others' processes and challenges: 
"... the environment in Circle House ... we were around the same table and looking at the same thing, at the same time (... ) we are all connected to each other and we all need to understand each other's businesses and somehow cooperate to make it happen ... "

One of the interviewees responsible for developing concrete elements for the Circle House project expresses the importance of new forms of collaborating for improving each other's solutions in order to accomplish a common goal:

"in the beginning there were a lot of crossed arms, because they (concrete elements producer) wanted to be circular, but didn't want to change anything (in the production process), but then after being put in the same room with the same challenge... having the same agenda and the same issues we wanted to solve ... we ended up having a system that was designed for disassembly and circular. And in the workshop, we also had the (company proving the concrete material and concrete joints) and the contractor, so we had all people around the table ... we were quickly able to have your idea approved or shot down by other disciplines that have something to say... it was really helpful and what was able to push the building industry further."

Establishing a collaborative learning platform is thus considered an enabler for addressing environmental, societal and economic interests on a 'system' dimension. Involved stakeholders do not simply improve their own CE practices but join forces, and collective value for the whole 'system' can be generated.

With regard to the role of information technologies in a CE, the study suggests that technology for monitoring performance of concrete and buildings is considered a supporting tool for realizing CE. Based on the case data, a number of concrete companies are implementing diverse sensors and chips containing information regarding material properties and disassembly possibilities. Yet, even though existing, that technology is neither fully developed, nor entirely utilized. Active use of the data on building performance is considered able to support the development or further improvement of user-oriented solutions if collaboration between concrete producers, contractor, maintenance company, IT support, users, is also in place. However, a number of issues related to data control and data ownership, data storage rights, and limited efficient use of the generated data, do exist. Interviewee 6 states:

"...every element has a cast-in chip and is all hooked up to a database. You only need to scan it with a phone and you can get all the needed information as a test to see what we can do and what we can use it for .... There are a lot of issues and different concerns we need to address. It is also a big discussion who should own this data. It could be service we provide and give access to the data database. If we should provide it as a service, it could be a business opportunity for us and one of the drivers (of CE) actually."

Interviewee 6 furthermore adds:

"If the data is owned by a provide company, there is always a risk that that company won't exist in 30 years or so, and what should then be done with ensuring the data availability ..."

\section{Discussion}

To answer the raised research question, a broader perspective is needed on the concepts of 'product', 'service' and 'system' than currently considered. The suggested conceptual framework enables the embeddedness of the different layers of interactions in the context of the concrete industry in Denmark within each dimension, in contrast to other developed frameworks in the literature, which do not capture adequately the systemic nature of a CE transformation. For instance, a framework developed by Ruiz et al. [55] takes a process flow approach, assuming a linear sequence of a CE procession (e.g., reuse and/or recycling of building components). On the other hand, Hopkinson et al. [56] use the 'building blocks' approach, suggested by Planing [57], to present the systemic interactions of CE transition, a method which does not adequately describe the interactions between the building blocks. 
In the proposed framework in this contribution, the three embedded dimensions are meant to capture conceptually the essence of 'product', 'service' and 'system' and to illustrate the level of interaction, starting from the 'product' dimension and reaching the 'system' dimension.

At the 'product' dimension, the price of concrete is tightly linked to its production costs and customers are generally still reluctant to pay extra for "greener" product. Thus, according to producers, having a 'product' focus leaves only little room for improvement potential if the end-price for users is not to be affected. This is generally considered a major barrier in CE undertakings in any business [58], and especially in the construction sector which exhibits sensitivity in product-price demand [59]. Similarly, with regard to realizing CE in 'products', the current focus of the concrete industry and related companies is placed on minimizing concrete waste on a factory level and recycling aggregates after demolition, in line with general EU practices $[60,61]$. Such activities are beneficial from both an environmental, social and in general economic terms. Yet, results from this study suggest that, if the focus of both producers and users is shifted from the 'product' and directed at the 'service' and the 'system', additional value for both industry, society, and the environment could be generated.

With a 'service' mind-set, long lasting buildings can be designed to be flexible and change function based on existing - and future-needs, including changes in architectural preferences. In addition, their performance can be monitored for possible improvements. The conducted interviews highlight the important supporting role of information technologies for a CE in all three dimensions, especially with regard to the 'service' and 'system'. Several IT-enabled techniques can assist monitoring of building materials and components and enable the designers and contractors to identify reuse opportunities, for example by using Building Information Modeling (BIM) [62]. However, results also reveal that there are a number issues related to information technologies in the concrete industry linked to the still low level of maturity of those solutions, as well as matters of data control and ownership.

With a 'system' perspective in focus, for CE to be realized, organizations involved in the development of a defined area need to set-up collaborative networks and be open to implement changes in their established processes or improve their end-products to be able to address the current and possible future needs of the given area. Public actors seem to play a pivotal role in creating the enabling conditions for the associated stakeholders to communicate and collaborate. Firstly, by setting clear technical requirements (e.g., through building codes), the necessary conditions for harmonization of business offerings with a CE perspective can be achieved [63]. Moreover, stakeholders with appropriate technical capacities, i.e., building certification organization, can also play a role in aligning producers and users of buildings in finding a common language in technical and economic requirements in new construction (or renovation) and reuse [64].

Addressing CE from a 'system' perspective allows looking beyond the practice of individual stakeholders. The stakeholder set-up of the "Circle House" project exemplifies that the 'system' consists of stakeholders who interact and that the key for those stakeholders is the "learning process" around developing systemic CE solutions. Results show that 'system' building calls for the development of new forms of organization and collaboration, as well as expansion of networks, within and across different stakeholder groups. However, it is important to stress that organizing a 'system' set-up could be challenging for stakeholders, as they would need to collaborate in new ways than currently established and be prepared to adapt own solutions to fit the current and possibly future 'system' needs. That is the case especially in the context of the building and construction industry, due to factors, such as (i) long lifetime of construction materials/buildings, (ii) possible changes of building ownership during use phase, and (iii) complex decision-making structure due to multiple stakeholders involved (i.e., investors, public authorities, architects, developers, suppliers, final users, etc.). Therefore, this study suggests that getting involved in projects, such as "Circle House", create an ideal collaborative learning platform and a space for 'proof of concept'. 


\section{Conclusions}

Departing from the established concept of PSS as a CE strategy [65-67], a framework was proposed to encompass a systemic approach at a higher level, beyond the product-service interaction. Such a holistic view of the 'product', 'service' and 'system' set out to highlight the underlying CE opportunities and challenges of CE transitioning by the concrete industry, as well as the role of inter-organizational collaboration.

Results from the case study analysis suggest a shift from a 'product' to a 'system' focus can generate more value for the industry, society, and the environment. A 'product' focus may lead to savings on input material cost, improved efficiency of resource use, and reduced concrete waste quantities. A 'service' focus, when supported by continuous monitoring of performance for possible renovation and improvements, can slow and delay the end-of-use of buildings. That can bring new market opportunities for concrete producers to adapt solutions to users' needs.

Addressing CE from a 'system' perspective makes it possible to look beyond the practice of individual stakeholders. In a 'system', stakeholders responsible for the development and maintenance of the built environment in a given urban area are considered interconnected. Key aspects for developing systemic CE solutions are a collaborative learning platform and shared goals. As such, a 'system' focus calls for new forms of organization and collaboration, as well as expansion of networks within and across different stakeholder groups. Zhang and Mei [68] studied how managerial learning could contribute to sustainable development and suggested creating collaborative learning platforms could have a positive effect on the long-term development of organizations. Further studies can examine how collaborative learning platforms can contribute to accomplishing long-term CE strategies of enterprises. Moreover, besides technological, market, and organizational aspects of a 'system' perspective, it is equally important to take into consideration the regulatory framework in which urban planning and construction activities are embedded. A holistic policy framework that enables CE in construction, both by establishing a top-down regulatory landscape and by facilitating bottom-up business innovation would be necessary to integrate in the 'system' perspective. Future research could build upon existing literature [69] and develop specific rules applicable to the construction sector in general, and the concrete industry in particular. That would enable expanding further the conceptual framework presented in this study by including direct policy considerations.

This study is based on a single industry case, which makes it possible to conduct a relative in-depth analysis of the concrete industry in terms of the underlying CE potentials in 'product', 'service' and 'system'. Yet, the authors acknowledge the limitations of the applied method and the need of expanding the focus to other contexts in order to increase the legitimacy of the findings. Through broadening the industry scope, further analysis of the prerequisites and motivators for industries to get involved in a multi-stakeholder set-up and establish shared goals can be conducted. Furthermore, collaboration is considered present in all three dimensions, and especially in 'service' and 'system', where it can play a key role in realizing CE opportunities. Thus, the concrete industry could benefit from in-depth stakeholder analysis of different levels of collaborative activities required in each dimension and the role they can have on realizing CE. Finally, the analytical approach in this article could be adopted in further studies to analyze other industrial sectors across the three dimensions, and to validate the conceptual framework a useful (or not) tool for examining diverse industrial settings towards realizing $\mathrm{CE}$.

Author Contributions: Y.K.R. contributed to all aspects of the research presented in this paper. R.M.M. supported the development of the conceptual framework for this study, as well as drafting, review, and editing the manuscript. L.M. thoroughly supported developing the methodology of the study, as well as reviewing the manuscript. All authors took active part in the data collection process. All authors have read and agreed to the published version of the manuscript.

Funding: This research received no external funding. 
Acknowledgments: The authors of this research would like to thank all the participants in the conducted interviews and follow-up dialogues for providing relevant insights on realizing CE in the context of the concrete industry. The authors furthermore thank Søren Kerndrup for his inputs and feedback, which undoubtedly help improve this paper.

Conflicts of Interest: The authors declare no conflict of interest.

\section{References}

1. Korhonen, J.; Honkasalo, A.; Seppälä, J. Circular economy: The concept and its limitations. Ecol. Econ. 2018, 143, 37-46. [CrossRef]

2. IPCC. Summary for Policymakers; Intergovernmental Panel on Climate Change (IPCC): Geneva, Switzerland, 2018.

3. Oberle, B.; Bringezu, S.; Hatfield-Dodds, S.; Hellweg, S.; Schandl, H.; Clement, J.; Cabernard, L.; Che, N.; Chen, D.; Droz-Georget, H.; et al. Global Resources Outlook 2019: Natural Resources for the Future We Want; A Report of the International Resource Panel. United Nations Environment Programme. Nairobi, Kenya; IRP: Paris, France, 2019.

4. WBCSD. The Cement Sustainability Initiative (CSI) Recycling Concrete Excutive Summary; World Business Council for Sustainable Development: Geneva, Switzerland, 2009.

5. Scrivener, K.L.; John, V.M.; Gartner, E.M. Eco-efficient cements: Potential economically viable solutions for a low- $\mathrm{CO}_{2}$ cement-based materials industry. Cem. Concr. Res. 2017, 114, 2-26. [CrossRef]

6. Akhtar, A.; Sarmah, A.K. Construction and demolition waste generation and properties of recycled aggregate concrete: A global perspective. J. Clean. Prod. 2018, 186, 262-281. [CrossRef]

7. Tam, V.W.Y. Economic comparison of concrete recycling: A case study approach. Resour. Conserv. Recycl. 2008, 52, 821-828. [CrossRef]

8. Li, X. Recycling and reuse of waste concrete in China. Part II. Structural behaviour of recycled aggregate concrete and engineering applications. Resour. Conserv. Recycl. 2009, 53, 107-112. [CrossRef]

9. Zhao, Z.; Courarda, L.; Groslambertb, S.; Jehinc, T.; Léonardb, A.; Xiao, J. Use of recycled concrete aggregates from precast block for the production of new building blocks: An industrial scale study. Resour. Conserv. Recycl. 2020, 157, 104786. [CrossRef]

10. Ghaffar, S.H.; Burman, M.; Braimah, N. Pathways to circular construction: An integrated management of construction and demolition waste for resource recovery. J. Clean. Prod. 2020, 244, 118710. [CrossRef]

11. Huuhka, S.; Kaasalainen, T.; Hakanen, J.H.; Lahdensivu, J. Reusing concrete panels from buildings for building: Potential in Finnish 1970s mass housing. Resour. Conserv. Recycl. 2015, 101, 105-121. [CrossRef]

12. Maerckx, A.-L.; D'otreppe, Y.; Scherrier, N. Building circular in Brussels: An overview through 14 inspiring projects. IOP Conf. Ser. Earth Environ. Sci. 2019, 225, 12059. [CrossRef]

13. McAloone, T.C.; Pigosso, D.C.A. Designing product service systems for a circular economy. In Designing for the Circular Economy; Charter, M., Ed.; Routledge: Abingdon, UK, 2018; pp. 102-112.

14. Pieroni, M.P.P.; McAloone, T.C.; Pigosso, D.C.A. From theory to practice: Systematising and testing business model archetypes for circular economy. Resour. Conserv. Recycl. 2020, 162, 105029. [CrossRef]

15. Huang, G.Q.; Qu, T.; Zhong, R.Y.; Li, Z.; Yang, H.D.; Zhang, Y.F.; Chen, Q.X.; Jiang, P.Y.; Chen, X. Establishing production service system and information collaboration platform for mold and die products. Int. J. Adv. Manuf. Technol. 2011, 52, 1149-1160. [CrossRef]

16. Green Building Council Denmark. Cirkulaer Økonomi og DGNB-Guide til Cirkulaere Principper i DGNB Baeredygtighedscertificering; Green Building Council Denmark: Copenhagen, Denmark, 2018.

17. Tebbatt, K.; Bsc, A.; Ba, M.O.; Thorpe, T.; Dean, M.; Bsc, J.T. Circular economy in construction: Current awareness, challenges and enablers. Waste Resour. Manag. 2017, 170, 15-24.

18. Ramsheva, Y.; Prosman, E.J.; Wæhrens, B.V. Dare to make investments in industrial symbiosis? A conceptual framework and research agenda for developing trust. J. Clean. Prod. 2019, 223, 989-997. [CrossRef]

19. Bocken, N.; Short, S.W.; Rana, P.; Evans, S. A literature and practice review to develop sustainable business model archetypes. J. Clean. Prod. 2014, 65, 42-56. [CrossRef]

20. Tate, W.L.; Bals, L.; Bals, C.; Foerstl, K. Seeing the forest and not the trees: Learning from nature's circular economy. Resour. Conserv. Recycl. 2019, 149, 115-129. [CrossRef] 
21. Høibye, L.; Sand, H. Circular Economy in the Nordic Construction Sector: Identification and Assesment of Potential Policy Instruments That Can Accelerate a Transition toward a Circular Economy; Nordic Council of Ministers: Copenhagen, Denmark, 2018.

22. Leising, E.; Quist, J.; Bocken, N. Circular economy in the building sector: Three cases and a collaboration tool. J. Clean. Prod. 2018, 176, 976-989. [CrossRef]

23. Konietzko, J.; Bocken, N.; Hultink, E.J. Circular ecosystem innovation: An initial set of principles. J. Clean. Prod. 2020, 253, 119942. [CrossRef]

24. Bocken, N.; de Pauw, I.; Bakker, C.; van der Grinten, B. Product design and business model strategies for a circular economy. J. Ind. Prod. Eng. 2016, 33, 308-320. [CrossRef]

25. Konietzko, J.; Bocken, N.; Hultink, E.J. A tool to analyze, ideate and develop circular innovation ecosystems. Sustainability 2020, 12, 417. [CrossRef]

26. Murray, A.; Skene, K.; Haynes, K. The circular economy: An interdisciplinary exploration of the concept and application in a global context. J. Bus. Ethics 2017, 140, 369-380. [CrossRef]

27. Levin, S.A. Self-organization and the emergence of complexity in ecological systems. BioScience 2005, 55, 1075-1079. [CrossRef]

28. Schöggl, J.P.; Stumpf, L.; Baumgartner, R.J. The narrative of sustainability and circular economy-A longitudinal review of two decades of research. Resour. Conserv. Recycl. 2020, 163, 105073. [CrossRef]

29. Baldassarre, B.; Keskin, D.; Diehl, J.C.; Bocken, N.; Calabretta, G. Implementing sustainable design theory in business practice: A call to action. J. Clean. Prod. 2020, 273, 123113. [CrossRef]

30. Corvellec, H.; Stål, H.I. Evidencing the waste effect of Product-Service Systems (PSSs). J. Clean. Prod. 2017, 145, 14-24. [CrossRef]

31. Chen, Z.; Huang, L. Application review of LCA (Life Cycle Assessment) in circular economy: From the perspective of PSS (Product Service System). Procedia CIRP 2019, 83, 210-217. [CrossRef]

32. Michelini, G.; Moraes, R.N.; Cunha, R.N.; Costa, J.M.H.; Ometto, A.R. From linear to circular economy: PSS conducting the transition. Procedia CIRP 2017, 64, 2-6. [CrossRef]

33. Halstenberg, F.A.; Stark, R. Introducing product service system architectures for realizing circular economy. Procedia Manuf. 2019, 33, 663-670. [CrossRef]

34. Kühl, C.; Tjahjono, B.; Bourlakis, M.; Aktas, E. Implementation of circular economy principles in PSS operations. Procedia CIRP 2018, 73, 124-129. [CrossRef]

35. Reim, W.; Parida, V.; Örtqvist, D. Product-Service Systems (PSS) business models and tactics-A systematic literature review. J. Clean. Prod. 2015, 97, 61-75. [CrossRef]

36. Tukker, A. Product services for a resource-efficient and circular economy-A review. J. Clean. Prod. 2015, 97, 76-91. [CrossRef]

37. Annarelli, A.; Battistella, C.; Nonino, F. Product service system: A conceptual framework from a systematic review. J. Clean. Prod. 2016, 139, 1011-1032. [CrossRef]

38. Han, J.; Heshmati, A.; Rashidghalam, M. Circular economy business models with a focus on servitization. Sustainability 2020, 12, 8799. [CrossRef]

39. Goedkoop, M.J.; Halen, C.J.G.V.; Riele, H.R.M.T.; Rommens, P.J.M. Product Service Systems—Ecological and Economic Basics; PricewaterhouseCoopers, Storrm, Pré Consultants for Ministry of Economic Affairs: The Hague, The Netherlands, 1999.

40. Kristensen, H.S.; Remmen, A. A framework for sustainable value propositions in product-service systems. J. Clean. Prod. 2019, 223, 25-35. [CrossRef]

41. Van Ostaeyen, J.; van Horenbeek, A.; Pintelon, L.; Duflou, J.R. A refined typology of product service systems based on functional hierarchy modeling. J. Clean. Prod. 2013, 51, 261-276. [CrossRef]

42. Chertow, M.R. Industrial symbiosis: Literature and Taxonomy. Annu. Rev. Energy Environ. 2000, 25, $313-337$. [CrossRef]

43. European Parliament. Directive 2008/98/EC of the European Parliament and of the Council of 19 November 2008 on Waste and Repealing Certain Directives; European Parliament: Brussels, Belgium, 2008.

44. Yin, R.K. Case Study Research: Designs and Methods; Sage Publications: London, UK, 2013.

45. Yin, R.K. Case Study Research and Applications, 6th ed.; Sage Publications, Inc.: Los Angeles, CA, USA, 2018. 
46. Mack-Vergara, Y.L.; John, V.M. Life cycle water inventory in concrete production-A review. Resour. Conserv. Recycl. 2017, 122, 227-250. [CrossRef]

47. Dansk Beton. Beton Styrker Bæredygtighed-Om Bæredygtige Fordele ved Beton; Dansk Beton: Copenhagen, Denmark, 2017.

48. Kleijer, A.L.; Lasvaux, S.; Citherlet, S.; Viviani, M. Product-specific Life Cycle Assessment of ready mix concrete: Comparison between a recycled and an ordinary concrete. Resour. Conserv. Recycl. 2017, 122, 210-218. [CrossRef]

49. The Danish Environmental Protection Agency. Genanvendelse af Knust Beton i nye Betonkonstruktioner; The Danish Environmental Protection Agency (EPA): Copenhagen, Denmark, 2018.

50. Ministry of Environment in Denmark. Udredning af Teknologiske Muligheder for at Genbruge og Genanvende Beton; Ministry of Environment in Denmark: Copenhagen, Denmark, 2015.

51. Jensen, K.G.; Sommer, J. Building a Circular Future, 3rd ed.; GNX: Copenhagen, Denmark, 2018.

52. Maxwell, J.A. Qualitative Research Design an Interactive Approach, 2nd ed.; Sage Publications, Inc.: Thousand Oaks, CA, USA, 2005.

53. Cembreau. Cement, Concrete $\mathcal{E}$ the Circular Economy: The Role of Cement in Concrete; Cembreau: Brussels, Belgium, 2016.

54. UN Environment (Ed.) Global Environment Outlook-GEO-6: Healthy Planet, Healthy People; Cambridge University Press: Cambridge, UK, 2019.

55. López Ruiz, L.A.; Ramón, X.R.; Gassó Domingo, S. The circular economy in the construction and demolition waste sector-A review and an integrative model approach. J. Clean. Prod. 2020, 248, 119238. [CrossRef]

56. Hopkinson, P.; Chen, H.M.; Zhou, K.; Wang, Y.; Lam, D. Recovery and reuse of structural products from end-of-life buildings. Proc. Inst. Civ. Eng. Eng. Sustain. 2018, 172, 119-128. [CrossRef]

57. Planing, P. Business model innovation in a circular economy reasons for non-acceptance of circular business models. Open J. Bus. Model Innov. 2015, 1, 1-11.

58. Guldmann, E.; Huulgaard, R.D. Barriers to circular business model innovation: A multiple-case study. J. Clean. Prod. 2020, 243, 118160. [CrossRef]

59. Wahlström, M.; Bergmans, J.; Teittinen, T.; Bachér, J.; Smeets, A.; Paduart, A. Construction and Demolition Waste: Challenges and Opportunities in a Circular Economy; European Environment Agency European Topic Centre Waste and Materials in a Green Economy: Copenhagen, Denamrk, 2020.

60. European Commission. EU Construction and Demolition Waste Protocol and Guidelines; European Commission: Brussels, Belgium, 2018.

61. European Commission. Resource Efficient Use of Mixed Wastes Improving Management of Construction and Demolition Waste Final Report; European Commission: Brussels, Belgium, 2017.

62. Akanbi, L.A.; Oyedele, L.O.; Akinade, O.O.; Ajayi, A.O.; Delgado, M.D.; Bilal, M.; Bello, S.A. Salvaging building materials in a circular economy: A BIM-based whole-life performance estimator. Resour. Conserv. Recycl. 2018, 129, 175-186. [CrossRef]

63. Nußholz, J.L.K.; Rasmussen, F.N.; Milios, L. Circular building materials: Carbon saving potential and the role of business model innovation and public policy. Resour. Conserv. Recycl. 2019, 141, 308-316. [CrossRef]

64. Copenhagen Resource Institute. Resource Efficiency in the Building Sector Final Report; Ecorys: Rotterdam, The Netherlands, 2014.

65. Da Costa Fernandes, S.; Pigosso, D.C.A.; McAloone, T.C.; Rozenfeld, H. Towards product-service system oriented to circular economy: A systematic review of value proposition design approaches. J. Clean. Prod. 2020, 257, 120507.

66. Kjaer, L.L.; Pigosso, D.C.A.; Niero, M.; Bech, N.M.; McAloone, T.C. Product/service-systems for a circular economy: The route to decoupling economic growth from resource consumption? J. Ind. Ecol. 2019, 23, 22-35. [CrossRef]

67. Pieroni, M.P.P.; McAloone, T.C.; Pigosso, D.C.A. Configuring new business models for circular economy through product-service systems. Sustainability 2019, 11, 3727. [CrossRef] 
68. Zhang, N.; Mei, L. Sustainable development in the service industry: Managerial learning and management improvement of Chinese retailers. Sustainability 2020, 12, 1430. [CrossRef]

69. Milios, L. Policy Framework for Material Resource Efficiency Pathway Towards a Circular Economy; The International Institute for Industrial Environmental Economics (IIIEE): Lund, Sweden, 2020.

Publisher's Note: MDPI stays neutral with regard to jurisdictional claims in published maps and institutional affiliations.

(C) 2020 by the authors. Licensee MDPI, Basel, Switzerland. This article is an open access article distributed under the terms and conditions of the Creative Commons Attribution (CC BY) license (http://creativecommons.org/licenses/by/4.0/). 